\title{
ASSESSMENT OF THE COMPETITIVENESS OF UKRAINE AND THE QUALITY OF LIFE OF THE POPULATION
}

\author{
Cherep A.V., Voronkova V.G., Kurdupa V.S. \\ Zaporizhzhia National University \\ Ukraine, 69600, Zaporizhzhia, Zhukovsky str., 66 \\ cherep.av.znu@gmail.com, valentinavoronkova236@gmail.com \\ ORCID 0000-0001-5253-7481, ORCID: 0000-0002-0719-1546
}

Key words:

competitiveness, standard of living, index of economic freedom, index of ease of doing business, index of global competitiveness, potential.
Competitiveness is one of the main indicators of state development. The problem of Ukraine's low level of competitiveness is quite relevant. It is characterized by low living standards, socio-political atmosphere in the country, the state and level of development of the financial system and production efficiency. The article examines the current level of competitiveness of the country and the quality of life of the population, formed the essence of this concept and identified its main quantitative characteristics, analyzed the potential of Ukraine for the future. This study analyzes the main features of the Ukrainian economy and its place against the background of the international economy on the basis of the world competitiveness rating. The main indices are considered, namely: the Ease of doing business index, the index of economic freedom in the country (Index of Economic Freedom) and the index of global competitiveness (The Global Competitiveness Index). However, ways to increase Ukraine's competitive position in the international arena are proposed.

\section{ОЦІНКА КОНКУРЕНТОСПРОМОЖНОСТІ УКРАЇНИ І ЯКОСТІ ЖИТТЯ НАСЕЛЕННЯ}

\author{
Череп А.В., Воронкова В.Г, Курдупа В.С. \\ Запорізький наиіональний університет \\ Украӥна, 69600, м. Запоріжжся, вул. Жуковського, 66
}

\section{Ключові слова:}

конкурентоспроможність, рівень життя, індекс економічної свободи, індекс легкості ведення бізнесу, індекс глобальної конкурентоспроможності, потенціал.

\begin{abstract}
Конкурентоспроможність є одним з основних показників розвитку держави. Проблема низького рівня конкурентоспроможності України є досить актуальною. Характеризується низьким рівнем життя, соціально-політичною атмосферою в країні, станом та рівнем розвитку фінансової системи та ефективністю виробництва. У статті досліджено сучасний рівень конкурентоспроможності країни та якість життя населення, сформовано сутність цієї концепції та визначено іï основні кількісні характеристики, проаналізовано потенціал України на майбутнє. У цьому дослідженні проаналізовано основні особливості української економіки та іiі місце на тлі міжнародної економіки на основі світового рейтингу конкурентоспроможності. Розглядаються основні індекси, а саме: індекс легкості ведення бізнесу, індекс економічної свободи в країні (Індекс економічної свободи) та індекс глобальної конкурентоспроможності (Глобальний індекс конкурентоспроможності). Однак пропонуються шляхи підвищення конкурентних позицій України на міжнародній арені.
\end{abstract}

\section{Statement of the problem}

Global changes in the world prove that today the main indicator of economic development and quality of life is its competitiveness. Competitiveness should be considered from a theoretical, economic, sociological and statistical point of view. The high level of this indicator increases the inflow of investments and injection of capital in the country, qualified personnel and stimulates scientific and technological development. The problems of increasing competitive opportunities are quite relevant and are associated with the most efficient use of state potential. Unsatisfactory level of competitiveness today is characterized by low living standards, rising unemployment in the country, underdeveloped and stable financial system and macroenvironment of the country, and high inflation. All these factors negatively affect the economic development of our country and have a significant contribution to the aggravation of the crisis.

It is impossible to overcome the highlighted issues without a detailed study of the concept of competitiveness and assessment of the main factors of the indicator. 


\section{Analysis of recent research sources and publications}

Among the foreign scientists who formulated the concept of "competitiveness", analyzed the main factors influencing the indicator, studied the international competitive environment, ensured the competitiveness of individual countries, the following prominent people should be singled out: R. Kanter [1], S. Linder [2], J. Mill [3], R. Nelson [4], D. Ricardo [5], J. Robinson [6], P. Samuelson [7,8], A. Smith [9], J. Schumpeter [10].

The highlighted issues attract the attention of many scientists and practitioners, and a large number of studies indicate the relevance of this topic.

\section{Objectives of the article}

The aims of the article are to investigate the current level of competitiveness of Ukraine and the level of quality of life of citizens, to form the essence of this concept and to determine the main quantitative characteristics; to evaluate the index of global competitiveness, the index of economic freedom and the index of ease of doing business in the country, finally, to determine the potential for future growth.

\section{The main material of the research}

Competitiveness is one of the main categories widely used in the theory and practice of economic sciences, a multifaceted concept, which translated from Latin means rivalry, the struggle to achieve the best results [11, p. 28].

The American economist Michael Porter made a fundamental contribution to the disclosure of the concept of "competitiveness" and did a tremendous work of defining ways to define the term. He notes that competitiveness is the property of a good, service, subject of market relations to perform on the market at the same level with similar goods, services or competing subjects of market relations present there [12, p. 148].

Thus, competitiveness is considered the main indicator of the state of the country's economy and further prospects for its development. Many analytical centers of the world are engaged in its study. The Swiss institutions - The
World Economic Forum and the International Institute for Management Development are among the most respected and authoritative that conduct studies, which publish annually reports on the competitiveness of countries and relevant rankings.

One of the ten international indices is the Global Competitiveness Index (GCI), which is used to calculate the competitiveness of countries. In the next iteration, the countries are ranked in a certain sequence. Note that GCI was developed by scientists from the World Economic Forum (WFI) [13]. The index is calculated on 130 variables, from which in turn 12 basic indicators are formed. According to GCI research, Ukraine ranked 83rd in 2018, and in 2019 lost two positions and dropped to 85 , while Singapore, the United States and Hong Kong have been remained at the leading positions for the last three years.

Analyzing the 12 main indicators of the Global Competitiveness Index, we can see that Ukraine has lost its position in 4 out of 12 indicators, namely the "financial system" - decreased by 7 positions, "health" lost 7 positions compared to 2018, "infrastructure" remained unchanged, "innovation" has not undergone major changes. But finally in recent years (from 2017 to 2019) the indicator of "labor market" has been gaining a stable growth trend.

Despite slight improvements in 2019 compared to 2017 and 2018, Ukraine still ranks among the lowest place in terms of road quality - 114th place (first place -Singapore), organized crime - 110th place (the lowest is in Finland), property rights -128 th place in the world, protection of intellectual property, due to the uncompleted legal framework in which unscrupulous citizens find loopholes, ranks 118th, compared to Finland, which ranks 1 st on this indicator.

In 2019, there were two indicators that lost 7 positions, the "financial system", which ranks 136th among all countries. Such a low indicator is influenced by: insufficient financing of small and medium-sized businesses (112th place in the world, 3.4), insufficient venture capital, which does not stimulate innovation, low market capitalization, instability of banks, non-performing loans. The second

Table 1 - Interpretation of the category of competitiveness by different authors

\begin{tabular}{|l|l|}
\hline \multicolumn{1}{|c|}{ Author } & \multicolumn{1}{c|}{ Definition } \\
\hline I. Bazyliuk & $\begin{array}{l}\text { Competitiveness of the national economy - an economic category that characterizes the state } \\
\text { of social relations in the country to ensure conditions for stable efficiency of national production, } \\
\text { adapted to changes in world conditions and domestic demand based on the disclosure of national } \\
\text { competitive advantages and achieve better socio-economic parameters than competitors. }\end{array}$ \\
\hline World Economic Forum & Competitiveness is the country's ability to achieve consistently high GDP growth rates per capita. \\
\hline $\begin{array}{l}\text { International Institute for } \\
\text { Management Development }\end{array}$ & $\begin{array}{l}\text { Competitiveness is a real and potential opportunity of firms under the existing conditions to design, } \\
\text { manufacture, sell goods that are more attractive to consumers in terms of price and non-price } \\
\text { characteristics than the goods of their competitors. }\end{array}$ \\
\hline B. Hubskii & $\begin{array}{l}\text { Established competitiveness of the country - the ability to optimally realize its competitive } \\
\text { advantages, focusing on the constant increase in productivity among other things. }\end{array}$ \\
\hline B. Kvasniuk & $\begin{array}{l}\text { The competitiveness of a country is a set of factors specific to a particular national economy that can } \\
\text { ensure the supply of goods and services produced under the conditions of the latest technologies, } \\
\text { free and fair market and growing incomes, which is acceptable for international trade in terms } \\
\text { of price-quality ratio. }\end{array}$ \\
\hline $\begin{array}{l}\text { Economic Encyclopedia } \\
\text { (K. Shtalman, M. Driakhlov, } \\
\text { V. Hartman) }\end{array}$ & $\begin{array}{l}\text { The competitiveness of a country is the ability of one country's economy to compete with the } \\
\text { economies of other countries in terms of efficient use of national resources, increase the productivity } \\
\text { of the national economy and ensure on this basis a high and ever-increasing standard of living. }\end{array}$ \\
\hline
\end{tabular}

The table was created by the author based on the source [10] 


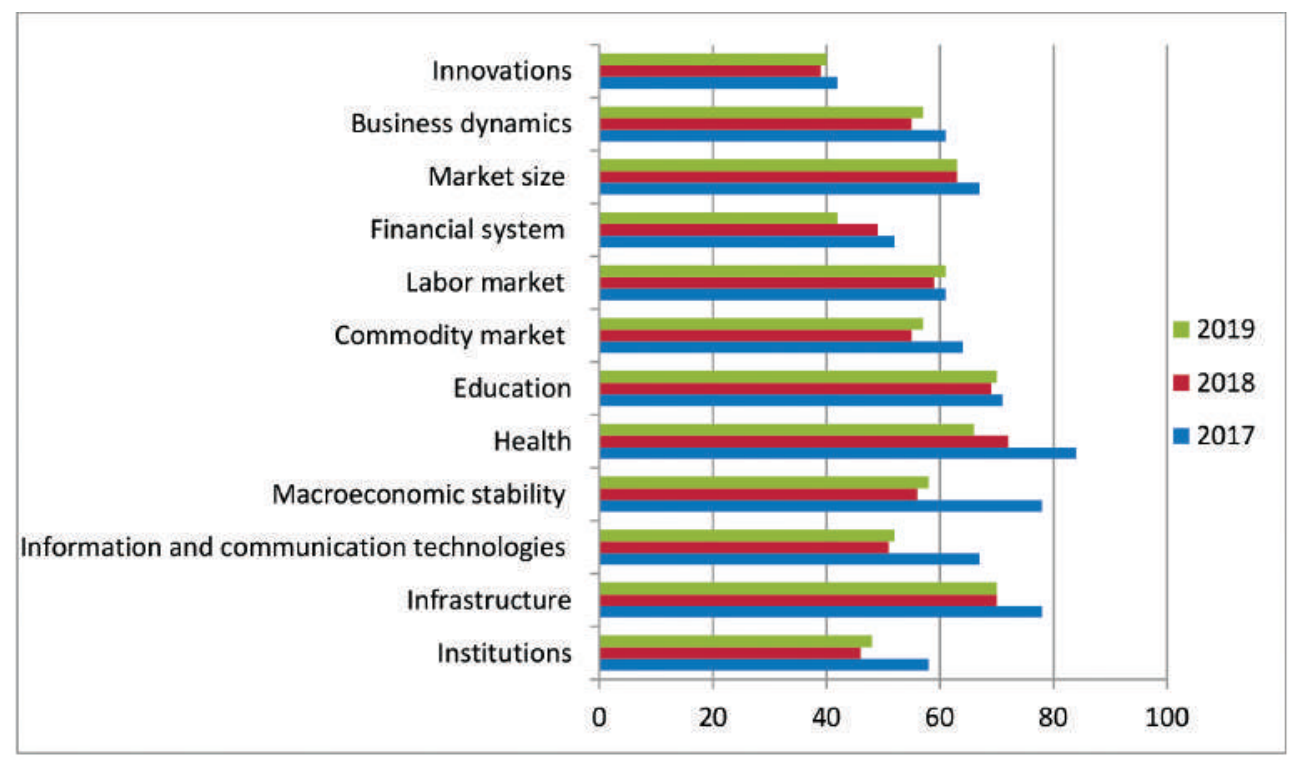

Fig. 1. Index of global competitiveness of Ukraine for 2017-2019

Created by the author on the basis of sources $[14 ; 15]$

indicator is "health", the main reason that we occupy 101st position in the world is life expectancy, which is on average 61 years in Ukraine.

Table 2 - Index of economic freedom of Ukraine 2018-2019

\begin{tabular}{|c|c|c|}
\hline Indicator & $\mathbf{2 0 1 8}$ & $\mathbf{2 0 1 9}$ \\
\hline Freedom of business & 62,7 & 66,1 \\
\hline Freedom of labor & 52,8 & 46,7 \\
\hline Monetary freedom & 60,1 & 58,6 \\
\hline Freedom of trade & 81,1 & 75 \\
\hline Investment freedom & 35 & 35 \\
\hline Financial freedom & 30 & 30 \\
\hline Property right & 41 & 43,9 \\
\hline Judicial efficiency & 29,5 & 31,5 \\
\hline Government intervention & 29 & 29,6 \\
\hline Tax burden & 80,2 & 81,8 \\
\hline Government spending & 45 & 46,9 \\
\hline Fiscal health & 75,9 & 82,6 \\
\hline
\end{tabular}

The table was developed by the author based on sources $[16 ; 17]$

An important component of assessing the competitiveness of Ukraine should be noted economic freedom. In 2019, Ukraine ranked 45th among European countries, experts determine the Ukrainian economy is the least free in Europe today.

Analyzing the table, we can see that the following indicators have undergone significant changes: fiscal health - the index increased by 7 compared to 2018 , business freedom - increased by 4 , and property rights - by almost 2.9. But most of the indices for 2019 fell, especiallyfreedom of trade, the index fell by 6 , monetary freedom by 2 , and freedom of labor - fell by 6 .

In Ukraine, the highest personal income tax rate is 20 percent, and the upper corporate tax rate is 18 percent.
The total tax burden is 35.5 percent of total domestic revenue. For the past three years, government spending has accounted for 42.8 percent of total output (GDP) and the budget deficit has averaged 2.6 percent of GDP. Public debt is equivalent to 81.2 percent of GDP.

The impetus for business reform has stalled, and political instability continues to exacerbate regulatory uncertainty in commercial operations. Ukraine has a welleducated and skilled workforce, but the labor code is outdated and not consistently enforced.

Trade is extremely important for Ukraine's economy; with a combined value of exports and imports 105 percent of GDP. The average applied tariff rate is 1.9 percent. Nontariff barriers hinder trade. The government's openness to foreign investment is below average. The Russian-Ukrainian conflict continues to hamper trade and investment flows.

Property rights are protected by the legislation of Ukraine, and mortgages and collateral are registered. There are serious issues regarding corruption in the judiciary, which is one of the weakest and least trusted public institutions in the country. Judges are generally considered as defenders of business and other powerful sources of influence. Corruption remains a serious problem for Ukraine and progress in economic stability. All this negatively affects the formation of state competitiveness in the international arena, and only inhibits economic development.

In order to compare the business environment in different countries around the world, each year the World Bank compiles the Ease of Doing Business Index, which is based on the study and quantification of national laws, rules and regulations on doing business.

In the assessment of the ease of doing business Doing Business-2019, Ukraine ranked 71st among 190 countries, thus it entered the hundredth ranking of the World Bank (New Zealand and Singapore continue to hold the first places). 


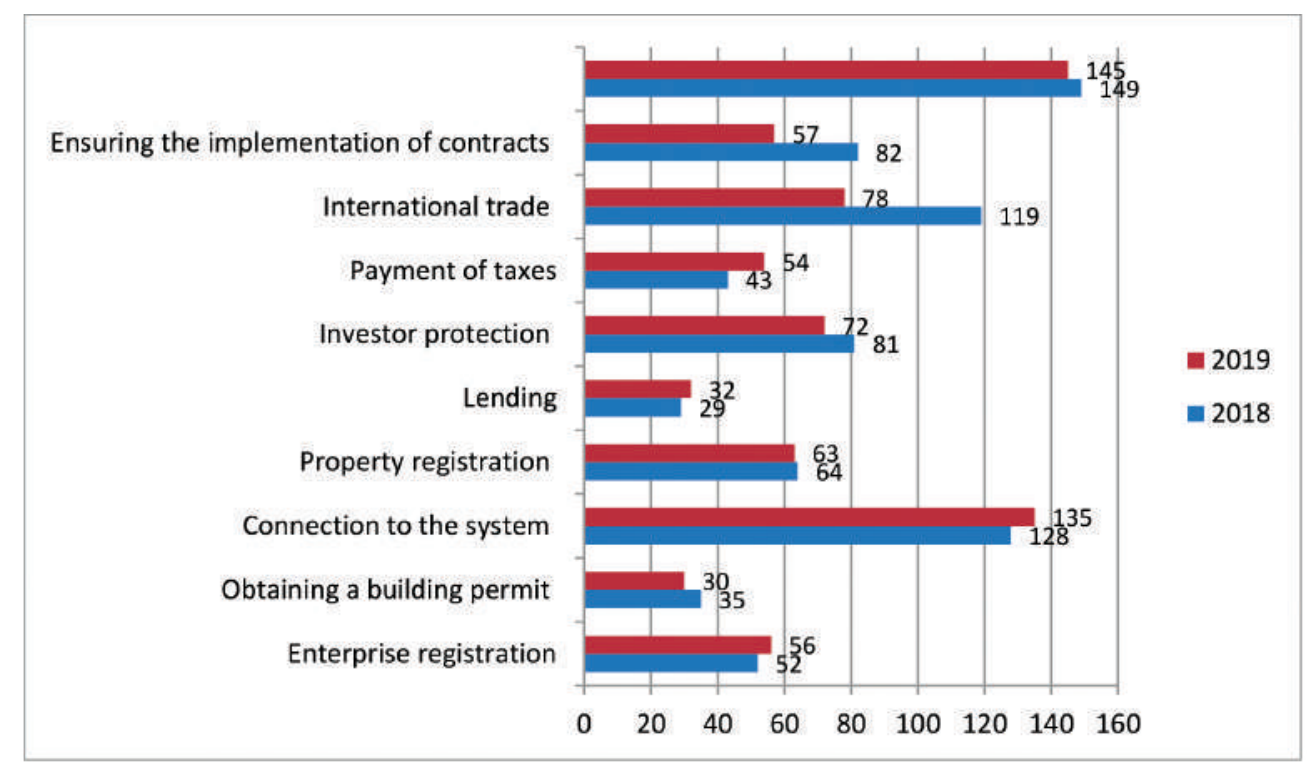

Fig. 2. Index of ease of doing business in Ukraine for 2018-2019

The figure was created by the author on the basis of sources [18; 19]

Analyzing the histogram, it is easy to see that Ukraine has reduced its position in some indicators, namely: registration of the company from 52 nd to 56 th place in the world, connection to the electricity system fell from 128 th to 135 th place, lending - from 29th to $32 \mathrm{nd}$, and paying taxes - from 43 rd to 54 th.

But it has improved its position on the following indicators: ensuring the execution of contracts from $82 \mathrm{nd}$ place to 57 th in the world, investor protection - from 81 st to 72nd place, obtaining a building permit - from 35 th place to 30th, international trade - from 119th to 78th place.

Among the changes that complicate doing business in Ukraine and lower our place in the world rankings, we can note the work with building permits, which the World Bank estimates 76.9 points out of 100 possible, obtaining a building permit will take 85 days, building quality control index estimated on 12 of 15 possible points.

Increasing Ukraine's competitiveness from 83 to 71 this year was ensured by the investor protection reform. The World Bank rated monetary investor protection at 58.3 out of 100 , the degree of disclosure at 8 out of 10 , the degree of corporate transparency at 8 , the shareholder rights 6 and the degree of ownership of the control index at 6 out of 10 . International trade has also undergone positive reforms: the estimate for cross-border trade is 77.6 out of 100 possible for exports, while border compliance is estimated at \$ 192 and documentary compliance at \$27. Imports are valued at $\$ 162$ for border compliance and $\$ 100$ for documentary receipt. Compared to last year, prices have decreased significantly, which increases Ukraine's competitiveness in the international commodity market [20].

For the transition of the domestic economy to a qualitatively new level of development and increase international competitiveness, it is necessary to develop a stable and effective system of public administration aimed at stimulating innovative development by supporting scienceintensive industries, demand for intellectual products and improving the legal framework for intellectual property protection, introduction of progressive innovations. It is necessary to create transparent courts and regulate the level of corruption, the introduction of anti-corruption courts and regular checks on the integrity of public servants, because it is the high level of corruption that "drives" potential investors from the state economy away from us. A high level of technological readiness could be the basis for increasing the competitiveness of Ukrainian companies in world commodity markets, and the introduction of advanced information and communication technologies will significantly increase the productivity of government agencies and significantly increase the country's rating of state institutions.

\section{Conclusions}

Thus, Ukraine's strategic priorities to increase the level of international competitiveness should be reflected in the system of gradual steps of adaptation of the national economy to changes in the leading countries of the world, to adapt to the globalization process. The main mechanism for increasing Ukraine's competitive advantage is the implementation of domestic reforms and studied for further establishment of foreign economic policy vectors. Also, the state's efforts should be aimed at creating a favorable business environment that will realize the existing innovation and human potential, will be attractive to investors and will be a prerequisite for a gradual increase in Ukraine's international competitiveness in world rankings.

\section{References}

1. Kanter R.M., B. Stein and T.D. Jick. The Challenge of Organizational Change: How Companies Experience It and Leaders Guide It. New York : Free Press, 1992. 456 p. 
2. Staffan Linder. An essay on trade and transformation. URL: http://seinst.ru/files/vehi_6_027_linder_k-voprosu-otorgovle.pdf.

3. Mill John Stuart. Oxford Dictionary of National Biography / C. Matthew. Oxford : OUP, 2004. 456 p.

4. The Life of Nelson A. Rockefeller: Worlds to Conquer, 1908-1958. New York : Doubleday, 1996. 486 c.

5. The Works Of David Ricardo Hardcover : Andesite Press, 2015. 638 p.

6. Joan Violet Robinson. The Economics of Imperfect Competition. London: Macmillan, 1933. 9“ x 6“. xii + 352 pp.

7. Paul Anthony Samuelson. The Observational Significance of Economic Theory: A Study in the Foundations of Analytical Economics. Harvard University, 1941. 908 p.

8. The Works of Paul Anthony Samuelson "Summing up“, Quarterly Journal of Economics, т. 80, 1966, c. 568

9. Samuelson Paul A., Nordhaus William D. Microeconomics, 18ed Williams. 2008. 752 c.

10. Adam Smith. An Inquiry into the Nature and Causes of the Wealth of Nations, Moscow : Exmo, 2007. (Series: Anthology of Economic Thought) 960 p.

11. Arnaut I.P. Research of approaches to the definition of competitiveness. Innovative economy. 2012. № 3. P. 111-114.

12. Porter M. International competition / M. Porter; [trans. with English ; under ed. and with a preface by V.D. Shchetinin]. Moscow : International Relations, 1993.896 p.

13. Didukh N. Global indices of competitiveness of national economies. Economic analysis. 2012. № April 10-16. pp. 133-136.

14. The Global Competitiveness Report 2019/ World Economic Forum. URL: http://www3.weforum.org/docs/WEF_ TheGlobalCompetitivenessReport 2019.pdf

15. The Global Competitiveness Report 2017-2018/ World Economic Forum. URL: http:/www3.weforum.org/docs/ GCR20172018/05FullReport /TheGlobalCompetitivenessReport2017\%E2\%80\%932018.pdf

16. The Heritage Foundation /2019 Index of Economic Freedom. URL: https://ueff.org/images/UEFF/content/indices/ heritage/heritage_index_2019.pdf

17. The Heritage Foundation/2018 Index of Economic Freedom. URL: https://ueff.org/images/UEFF/content/indices/ heritage/heritage index 2018.pdf

18. A World Bank Group Flagship Report/ Doing Business 2019/ URL: https://www.doingbusiness.org/content/dam/ doingBusiness/media/Annual-Reports/English/DB2019-report_web-version.pdf

19. A World Bank Group Flagship Report/ Doing Business 2018/ URL: https://www.doingbusiness.org/content/dam/ doingBusiness/media/Annual-Reports/English/DB2018-report_web-version.pdf.

20. Principles of competitiveness in the realities of the knowledge economy: Collective monograph / International Institute of Management (MIM-Kyiv); For science. ed. Yu.V. Poluneeva. Kyiv : LLC “Engineering“, 2016. 256 p. 